\title{
DESIGN AND ECONOMICAL OF ROOF TRUSSES \& PURLINS (COMPARISON OF LIMIT STATE AND WORKING STRESS METHOD)
}

\author{
A.Jayaraman', R Geethamani², N Sathyakumar ${ }^{3}$, N Karthiga Shenbagam ${ }^{4}$ \\ ${ }^{1}$ Assistant Professor, Department of Civil Engineering Bannari Amman Institute of Technology, Sathamangalam- \\ 638401, India. \\ ${ }^{2}$ Assistant Professor, Department of Civil Engineering Bannari Amman Institute of Technology, Sathamangalam- \\ 638401, India. \\ ${ }^{3}$ Assistant Professor, Department of Civil Engineering Bannari Amman Institute of Technology, Sathamangalam- \\ 638401, India. \\ ${ }^{4}$ Assistant Professor, Department of Civil Engineering Bannari Amman Institute of Technology, Sathamangalam- \\ 638401, India.
}

\begin{abstract}
For a structural design to be satisfactory, generally four major objectives - utility, safety, economical and elegance must be fulfilled. This paper presents a study on behaviour and economical of roof trusses and purlins by comparison of limit state and working stress method. Roof trusses and purlins are therefore an integral part of an industrial building and the like for supporting the roofing system. This paper presents a study on behaviour and economical of fink type roof trusses, channel section purlins by comparison of limit state and working stress method. This study involves in examination of theoretical investigations of specimens in series. Overall two methods were designed and comparison of all the internal force, economical, and hence, to evaluate the coexisting moments and shear forces at the critical cross-section with same configuration area by keeping all other parameters constant. The theoretical data are calculated using Indian Standard code IS 875-1975 (part III), IS 800 - 2007 using limit state method, IS 800- 1984 using working stress method and the section properties of the specimens are obtained using steel table. The specimens are designed under uniformly distributed loading with simply supported condition. The research project aims to provide which method is economical, high bending strength, more load carrying capacity and high flexural strength. The studies reveal that the theoretical investigations limit state method design is high bending strength, high load caring capacity, minimum deflection and minimum local buckling \& distortional buckling compare to the working stress method. But working stress method is most economical compare to the limit state method design.
\end{abstract}

Keywords bending strength, deflection, limit state method, purlins, roof trusses, working stress method. $* * *$

\section{INTRODUCTION}

Industrial buildings are low rise steel structures, characterized by their low height, lack of interior floors, walls and partitions. Roof trusses are elements of the structure composed of members subjected to direct stresses. Sometimes the truss is also called an open web beam. It consists of a triangular network of compression and tension members. On the basis of structural behaviour, roof trusses can be classified a simple roof trusses supported over masonry walls, and roof trusses supported over columns and connected to it with knee braces. Theoretically, truss members are subjected only to direct tension and direct compression. Purlins are beams provide over trusses to support the roofing between the adjacent trusses .these are placed in a tilted position over the principal rafters of the trusses. Channel and angle sections are commonly used purlins. Cold formed steel purlins are the widely used structural elements in India. Practically ' $Z$ ' sections are provided, where the span of the roof purlins is sloped and the length of the span is maximum. The main process of cold formed steel structural elements involves forming steel sections in cold state sheets at uniform thickness. The thickness of steel member ranges from $0.4 \mathrm{~mm}$ to $6.4 \mathrm{~mm}$. The cold forming operation increases the yield point and ultimate strength of the steel sections ${ }^{(1)}$. Light gauge steel sections are also known as cold formed steel sections. These sections are made from thin sheets of uniform thickness without the applications of heat. The thickness of the sheet used is generally between $1 \mathrm{~mm}$ and $8 \mathrm{~mm}$. These types of sections are extensively used in the building industry, as purlins girts, light struts roof sheeting, and floor decking. These sections become economical for light loads and to form useful surfaces such as roof covering, wall panels. Load carrying capacity should decreases with increase in Length and Width to thickness (W/t) ratio. Due to minimum thickness of cold rolled steel, considering the Local, torsional \& distortional buckling characteristics for its behaviour study most of the failures occurs at $1 / 3$ distance for $1,1.2 \mathrm{~mm}$ elements $\&$ at centre for $1.6,2 \mathrm{~mm}$ elements. the experimental investigation $2 \mathrm{~mm}$ thick cold formed steel "Long column with Web Stiffened" is preferable for "C Section"(2) . Various types of section may be manufactured using light gauge steel. They includes angles, channel with and without lips, hat section lipped Z Section etc.. Cold Formed steel product such as Z-purlin has been commonly 
used in metal building industry more than 40 year in unites state due to their wide range of application, economy, ease of fabrication and high strength-to-weight ratios. Z- Purlins are predominantly used in light load and medium span situations such as roof systems ${ }^{(3)}{ }^{4}$. The design of industrial building is governed mainly by functional requirements and the need for economy of construction. In cross-sections these buildings will range from single or multibay structures of larger span when intended for use as warehouses or aircraft hangers to smaller span buildings as required for factories, assembly plants, maintenance facilities, packing plants etc. The main dimensions will nearly always be dictated by the particular operational activities involved, but the structural designer's input on optimum spans and the selection of suitable cross-sections profile can have an important bearing on achieving overall economy. An aspect where the structural designer can make a more direct contribution is in lengthwise dimensions i.e. the bay lengths of the building. Here a balance must be struck between larger bays involving fewer, heavier main components such as columns, trusses, purlins, crane beams, etc. and smaller bays with a large number of these items at lower unit mass. An important consideration in this regard is the cost of foundations, since a reduction in number of columns will always result in lower foundation costs. Light gauge cold formed steel section channel section have high bending strength, high load caring capacity, minimum deflection and minimum local buckling \& distortional buckling compare to the built up channel section by same cross sectional area. The numerical investigation of channel section is the maximum bending moment, torsional moment and deformation is higher than the built up channel section by same cross sectional area ${ }^{(4)}$. There are several failure modes among which distortional buckling is one such failure mode that affects the strength of the section. In order to assess the influence of distortional buckling, a parametric study has been conducted by varying the lip depth, which is the influencing factor for distortional buckling strength ${ }^{(5)}$. Channels may be used as compression or flexural members. Hat section and $\mathrm{Z}$ section are used as flexural members. Hollow rectangular section used for variety of sections. Built up I section using Light gauge steel with lower $\mathrm{H} / \mathrm{t}$ aspect ratio behaves significantly showing elastic and plastic deformation both. With increment in $\mathrm{H} / \mathrm{t}$ aspect ratio this behaviour changes and shows failure in elastic zone ${ }^{(6)}$. Black bolts and high strength friction grip bolts may be used for the connection of the light gauge sections. However, high strength friction grip bolts are most suitable for the connection of light gauge sections. Advances in computational features and software have brought the finite element method within reach of both academic research and engineers in practice by means of general-purpose nonlinear finite element analysis packages, with one of the most used nowadays being ANSYS. The program offers a wide range of options regarding element types, material behaviour and numerical solution controls, as well as graphic user interfaces (known as GUIs), auto-meshers, and sophisticated postprocessors and graphics to speed the analyses. In this paper, the structural system modelling is based on the use of this commercial software. Several numerical modelling issues related to potential convergence problems, loading strategies and computer efficiency. The accuracy and simplicity of the proposed model make it suitable to predict and/or complement experimental investigations ${ }^{(7)}$.most of structural elements are analysis by using STADD pro and ANSYS.

\section{AIM OF THE STUDY}

The main aim of the study provides which method is most economical method and, high bending strength, more load carrying capacity and high flexural strength by analysis of both working stress and limit state method.

\section{3 .EXPERIMENTAL INVESTIGATION}

\subsection{Materials}

\subsubsection{Light Gauge Steel Physical Properties:}

The rolled steel sheet is used. The physical properties of light gauge steel section given in Table 1.The properties taken from the Indian Standard code IS 800-2007

Table 1 Physical properties light gauge steel section

\begin{tabular}{|l|l|}
\hline Density of steel ( e ) & $7850 \mathrm{~kg} / \mathrm{m}^{3}$ \\
\hline Modulus of elasticity, E & $2 \times 10^{5} \mathrm{~N} / \mathrm{mm}^{2}$ \\
\hline Poisson ratio & 0.3 \\
\hline Modulus of rigidity, G & $0.769 \times 10^{5} \mathrm{~N} / \mathrm{mm}^{2}$ \\
\hline $\begin{array}{l}\mathrm{CO} \text { efficient of thermal } \\
\text { expansion }(\alpha)\end{array}$ & $12 \times 10^{-6}$ \\
\hline
\end{tabular}

\subsubsection{Components of Roof Trusses:}

Principal rafter, sling, principal tie, strut, tie, bottom chord and top chord purlins, sag tie and bracing 


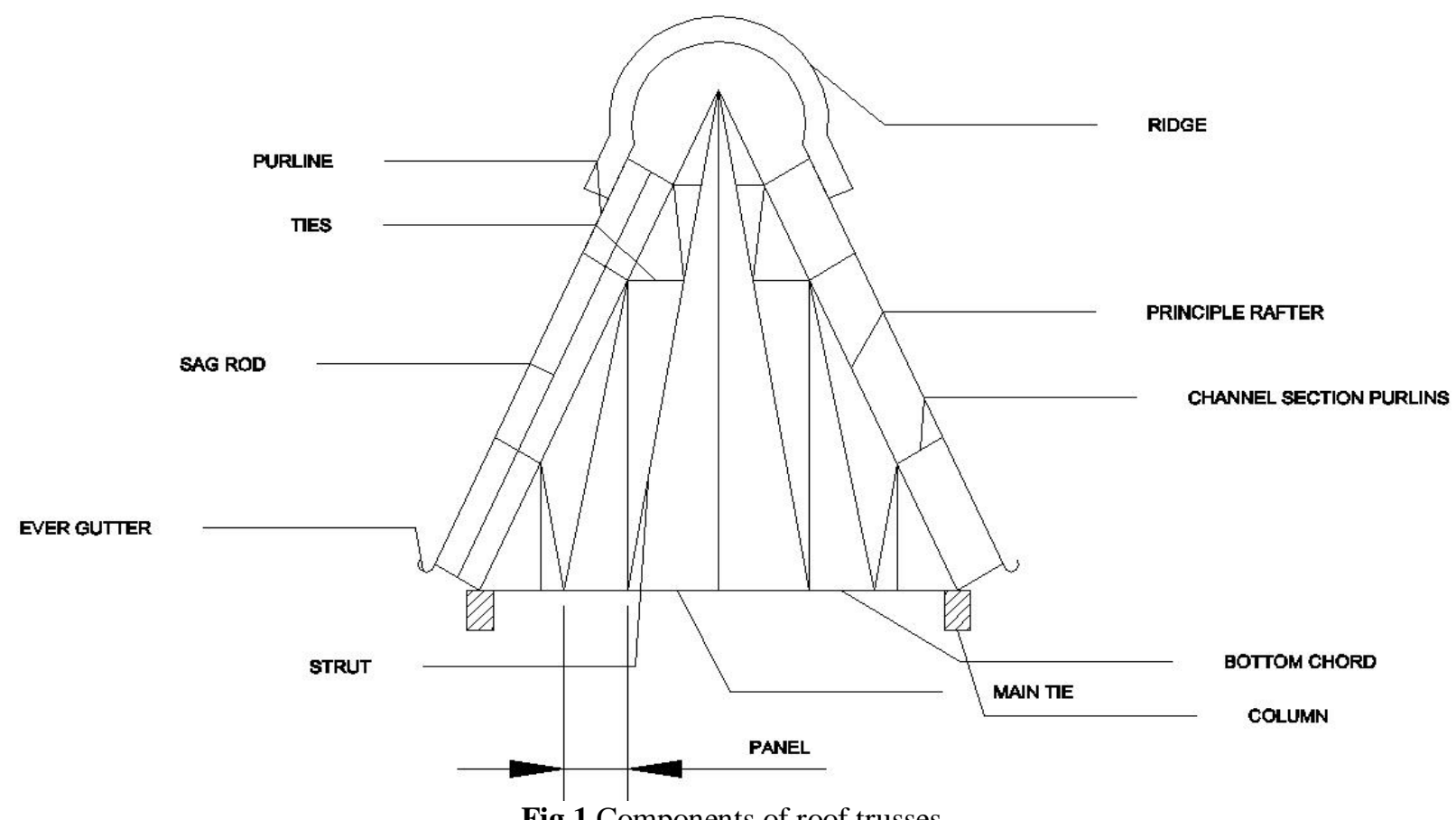

Fig 1 Components of roof trusses

\subsubsection{1principal Rafter}

Principal rafter is a post chord member in a roof truss and boom is the principal compression member in arcane.

\subsubsection{Stanchion}

Column, stanchion or post is a vertical compression member supporting floors or girders in a building. These compression members are subjected to heavy loads.

\subsubsection{Strut}

Strut is a compression member used in the roof truss and bracing. It is small span and lightly loaded compression member. A strut may be continuous or discontinuous. A continuous strut is a compression member which is continuous over a number of joints, such as a top chord member of a truss bridge girder, principal rafter of a roof truss etc.

\subsubsection{Purlins}

Purlins are beams provide over trusses to support the roofing between the adjacent trusses .these are placed in a tilted position over the principal rafters of the trusses. Channel and angle sections are commonly used purlins

\subsubsection{Sag Tie:}

The long middle tie member of the truss may sag because of its self weight and to check this sag tie may be provided.

\subsubsection{Loads on the Roof Truss:}

roof truss are subjected to dead load, live load, wind load and snow loads etc..

\subsubsection{Dead Load:}

The dead loads of the truss include the dead load of roofing materials, purlins, trusses and bracing system.

\subsubsection{Live Load:}

The imposed load on sloping roofs with slops up to and including 10 degree is to be taken as $0.75 \mathrm{kN} / \mathrm{m}^{2}$ of plan area .for roofs with slopes > 10degree, an imposed load $0.75 \mathrm{kN} / \mathrm{m}^{2}<0.02 \mathrm{kN} / \mathrm{m}^{2}$ for every degree increase in slope over 10 degree, subject to a minimum of $0.4 \mathrm{kN} / \mathrm{m}^{2}$ is to be taken for roof membrane.

\subsubsection{Snow Load:}

This load various with the region in which the structure is built. Actual load due to due to snow will depend upon the shape of the roof and its capacity to retain the snow. In case of roofs with slope greater than 50 degree, snow load may be disregarded.

\subsubsection{Wind Load:}

The most critical load on an industrial building is the wind load

$$
\text { Wind force }(F)=\left(\mathrm{Cp}_{\mathrm{e}}-\mathrm{Cp}_{\mathrm{i}}\right) \mathrm{A} \mathrm{P}_{\mathrm{d}}
$$

\subsubsection{Spacing of Roof Trusses:}

the usual economical spacing ranges between 4 and $8 \mathrm{~m}$ with the lower limit for short truss spans and higher limit for long spans of about $30 \mathrm{~m}$ or over. For span upto $18 \mathrm{~m}$ spacing should preferably be $4 \mathrm{~m}$ but not exceed $5 \mathrm{~m}$. For spans from $18 \mathrm{~m}$ to $25 \mathrm{~m}$ the spacing should not exceed $6 \mathrm{~m}$.in our case the spacing of trusses is limited to $6 \mathrm{~m}$. 


\subsection{Theoretical Investigations of Roof Trusses and}

\section{Purlins}

\subsubsection{Design of Roof Trusses}

The building is located in industrial area Coimbatore. Both ends of the truss are hinged.

Span of the roof truss is $=18 \mathrm{~m}$

Spacing of the trusses is $=4 \mathrm{~m}$

Height of building is $\quad=8 \mathrm{~m}$

Length of buildings is $=20 \mathrm{~m}$

Rise of the trusses $\quad=1$ in 4

Pitch of the roof trusses

$$
\operatorname{Pitch}(\mathrm{p})=\frac{\text { dept } h}{\text { span })}=4.5 \mathrm{~m}
$$

Slope of the roof $(\Theta)=26.56$

Length along the slopping roof $=10.06 \mathrm{~m}$

Length of each panel let us divide the length in to four equal parts length of each panel

$$
\text { Length of each panel }=\frac{\text { lengt } h \text { of slopping roof }}{4}=2.52 \mathrm{~m}
$$

\section{Load calculation}

\subsubsection{Design of Dead Load:}

The dead loads are taken from the steel table. The dead loads of the truss include the dead load of roofing materials, purlins, trusses and bracing system

Weight of roof covering (galvanised sheeting) $=150 \mathrm{~N} / \mathrm{m}^{2}$

Weight of purlins

$$
=100 \mathrm{~N} / \mathrm{m}^{2}
$$

Weight of wind bracing

$$
=15 \mathrm{~N} / \mathrm{m}^{2}
$$

Self Weight of trusses (span / $3+5) 10$

$$
=110 \mathrm{~N} / \mathrm{m}^{2}
$$

Total dead load of roof trusses $(\mathrm{Wd})$

$$
=375 \mathrm{~N} / \mathrm{m}^{2}
$$

Load at each intermediate panel due to dead load $=3375 \mathrm{~N}$

Load at each end panel due to dead load $\quad=1687.5 \mathrm{~N}$

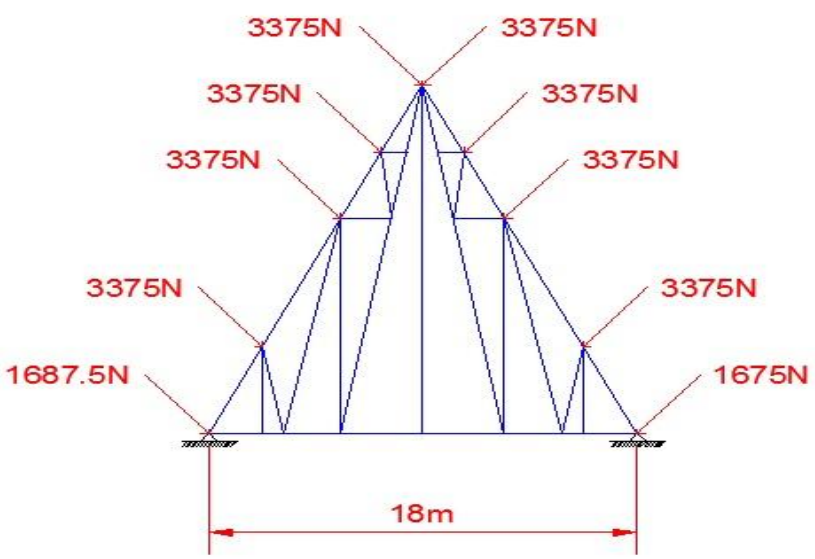

Fig 2 Dead load at panel points

\subsubsection{Design of Live Load:}

The live loads are taken from the steel table and IS 875 1975

Live load $=750-20 \times\left(26.56^{\circ}-10^{\circ}\right) \quad=418 \mathrm{~N} / \mathrm{m}^{2}$

Load at each intermediate panel due to live load $=3800 \mathrm{~N}$ Load at each end panel due to live load $\quad=1900 \mathrm{~N}$

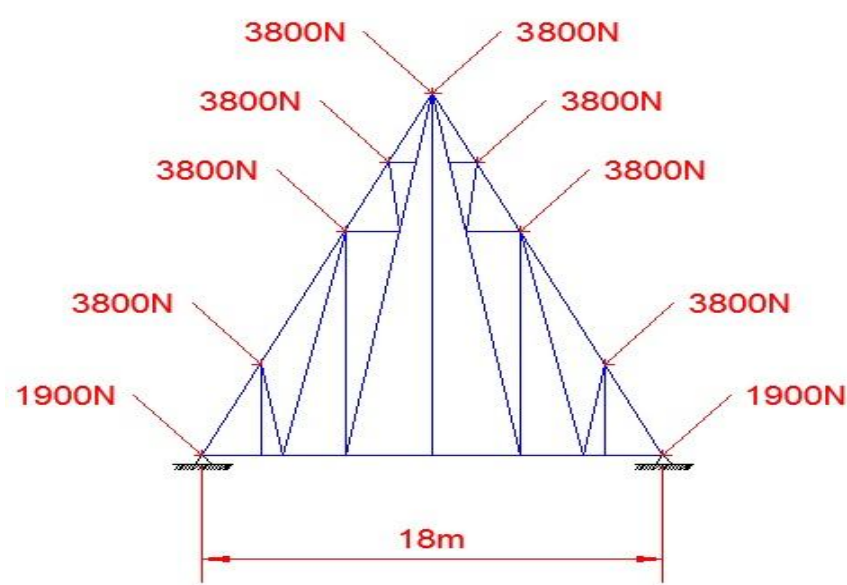

Fig 3 Live load at panel points

\subsubsection{Design of Wind Loads:}

Let us assume industrial building to be 50 years and the and the land to be plain and surrounded by small buildings.

Risk coefficient ( $\mathrm{k} 1$ ) taken from IS 875- $1975=1$ (life of building 50 years)

Terrains category $(\mathrm{k} 1)$ taken from IS 875- $1975=0.88$

Topography factor $(\mathrm{k} 3)$ taken from IS 875- $1975=1$ (plain ground)

Basic wind speed $\left(\mathrm{V}_{\mathrm{b}}\right)$ for zone 5 $=39 \mathrm{~m} / \mathrm{s}$

Design wind speed $\left(\mathrm{V}_{\mathrm{z}}\right)=\mathrm{k}_{1} \times \mathrm{k}_{2} \times \mathrm{k}_{3} \times \mathrm{V}_{\mathrm{b}}=34.44 \mathrm{~N} / \mathrm{m}^{2}$

Design wind pressure $\mathrm{P}_{\mathrm{d}}=\left(0.6 \mathrm{x} \mathrm{V}_{\mathrm{z}}{ }^{2}\right) \quad=711.66 \mathrm{~N} / \mathrm{m}^{2}$ 
An internal pressure coefficient depends upon the degree of permeability of cladding to the flow of air. The internal air pressure may be positive or negative depending on the direction of flow of air in relation to opening in the building. Building with small opening 0-5\% the an internal pressure coefficient +0.2 or -0.2 , Building with medium opening $5-$ $20 \%$ an internal pressure coefficient +0.5 or -0.5 , Building with large opening above $20 \%$ an internal pressure coefficient +0.7 or -0.7 .

An internal pressure coefficient +0.5 or -0.5 because of building with medium opening $5-20 \mathrm{~m}$. An external pressure coefficient +0.7 or -0.7 depends upon the height and width ratio wind ward and lee ward given in condition IS 875 -1975. Part III

Wind force $(F)=\left(C p_{e}-C p_{i}\right) \times A \times P_{d}=8160 \mathrm{~N}$

Load at each intermediate panel due to wind load = $3800 \mathrm{~N}$

Load at each end panel due to wind load $=1900 \mathrm{~N}$

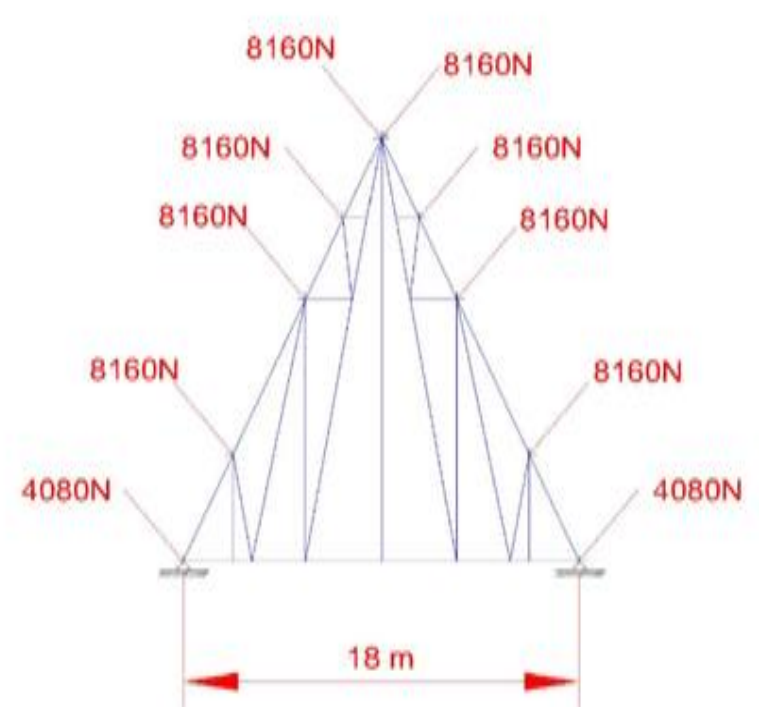

Fig 3 Wind load at panel points

\subsubsection{Theoretical Investigations of Purlins by}

\section{Working Stress Method}

Purlins section is subjected to biaxial bending by dead load and uniaxial bending by wind load, such bending is called unsymmetrical bending. Purlins may be designed as simple, continuous or cantilever beams. The simple beam design yields the greatest moments and deflections. The bending moment due to dead load and wind load are

Bending moment in $\mathrm{x}-\mathrm{x}$ direction $\mathrm{Mdx}=\frac{w d x \cos \theta \times B}{10}=$ $0.54 \mathrm{kNm}$
Bending moment in $\mathrm{y}-\mathrm{y}$ direction Mdy $\quad=\frac{w d x \sin \theta \times B}{10}=$ $0.279 \mathrm{kNm}$

Bending moment in wind direction Mwx $=\frac{w w \times B}{10}$ $=3.44 \mathrm{kNm}$

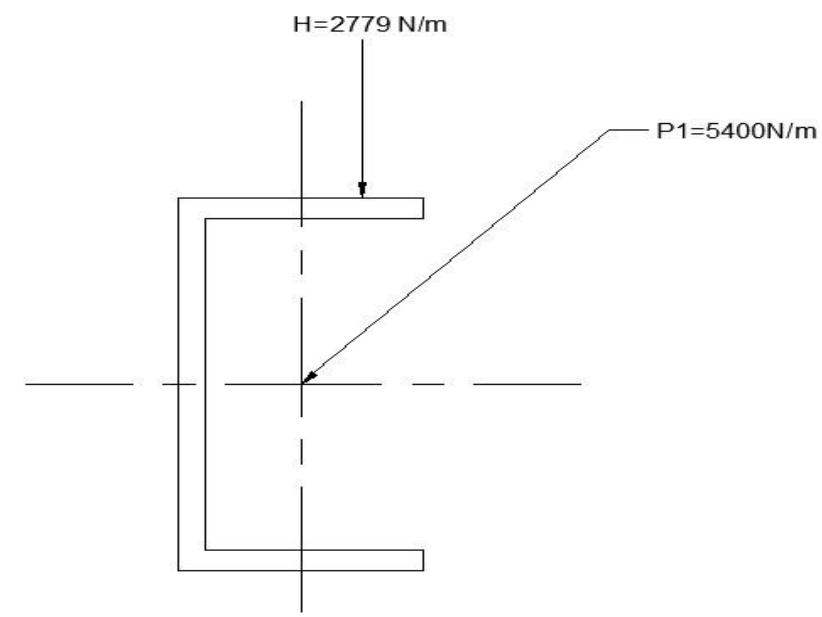

Where

$\mathrm{B}=$ Spacing of the truss

$\mathrm{Wd}=$ dead load, $\mathrm{ww}=$ wind load

Maximum Design moments $\mathrm{Mxx}=\mathrm{Mdx}+\mathrm{Mwx}=2.90$ $\mathrm{kNm}$

Section modulus $(\mathrm{Z})$ required $=\frac{M X}{\text { Bebding stress }(0.66 \times 250)}=$ $0.27 \mathrm{kNm}$

Selection of channel section $40 \%$ more than the actual section modulus. There fore

Let us provide ISMC $100 @ 92 \mathrm{~N} / \mathrm{m}, \mathrm{A}=1170 \mathrm{~mm}^{2}$

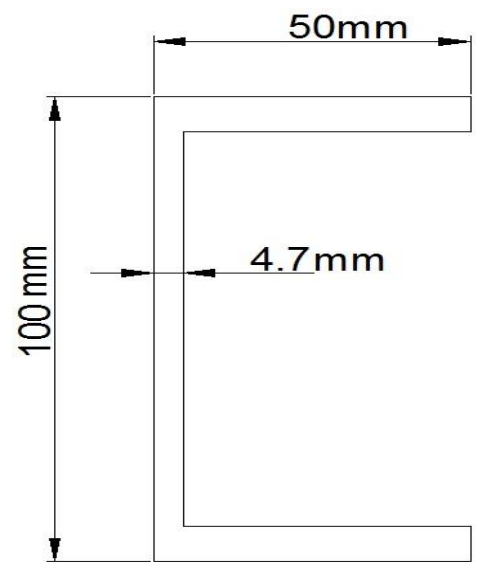

Relevant Properties of channel section $\mathrm{Zxx}=37.3 \times 10^{3}$ $\mathrm{mm} 3$, Zyy $=7.5 \mathrm{x} 103 \mathrm{~mm} 3$

Check for bending stresses $=\frac{M x x}{Z x x}+\frac{M y y}{Z y y} \quad=137.74 \mathrm{~N}$ $/ \mathrm{mm}^{2}$ 
The actual bending stress is $165 \mathrm{~N} / \mathrm{mm}^{2}$ and design bending stress is $137.74 \mathrm{~N} / \mathrm{mm}^{2}$

Hence section is safe $137.74 \mathrm{~N} / \mathrm{mm}^{2}<165 \mathrm{~N} / \mathrm{mm}^{2}$

\subsubsection{Theoretical Investigations of Purlins by Limit}

\section{State Method}

Limit state method

Dead load

$$
=375 \mathrm{~N} / \mathrm{m}^{2}
$$

Wind load

$$
=8160 \mathrm{~N}
$$

The component of dead load parallel to the roof $=375 \mathrm{x}$ $2.52 \times \sin 26.56$

The component of dead load normal to the roof $=375 \mathrm{x}$ $2.52 \times \cos 26.56$

Total load on purline normal to the roof $\quad=13085.27 \mathrm{~N} / \mathrm{m}$

Factored load normal to the roof $(\mathrm{p}) \quad=19627.905 \mathrm{~N} / \mathrm{m}$

Factored load parallel to the roof $(\mathrm{p}) \quad=633.8 \mathrm{~N} / \mathrm{m}$

The limit state method normal and parallel to the roof load diagram given below

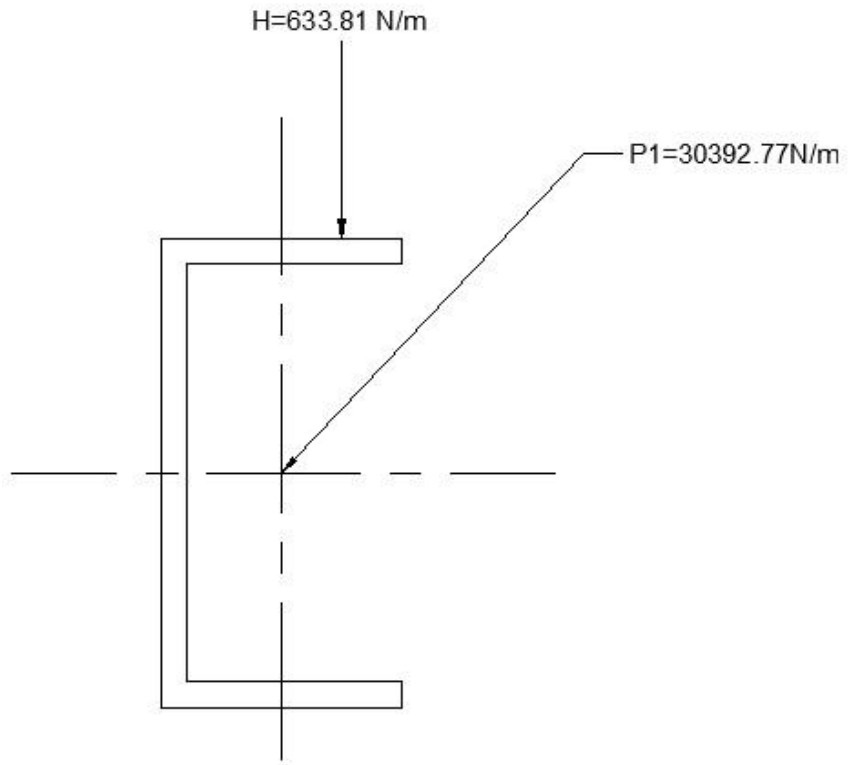

Maximum bending moment in $\mathrm{x}-\mathrm{x}$ direction $=\frac{P L}{10}=$ $12.157 \mathrm{kNm}$

$=\frac{H L}{10}$

Maximum bending moment in $\mathrm{y}-\mathrm{y}$ direction

$=12.157 \mathrm{kNm}$

Required plastic section modulus $(\mathrm{Z})$ required let us try to depth of the section $=300 \mathrm{~mm}$ and width of flange $=90 \mathrm{~mm}$ $(\mathrm{Z})_{\text {Required }}=+2.5\left(\frac{\text { Dept } h \text { of the section }}{\text { width of the flange }}\right) \times\left(\mathrm{My}\left(\frac{\gamma m o}{\mathrm{fy}}\right)\right.$
(Z) Required

$=62.76 \times 10^{3} \mathrm{~mm}^{3}$

Selection of channel section $40 \%$ more than the actual section modulus. There fore

Let us provide ISMC 150 @ 164 N/m

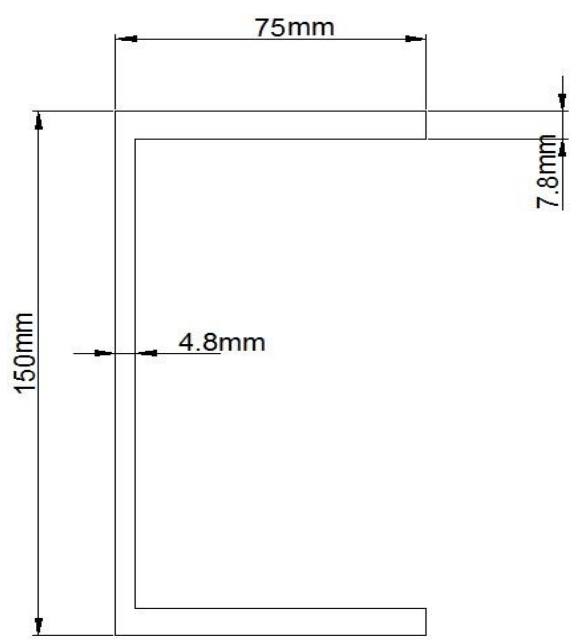

Area $=1836 \mathrm{~mm}^{2}$, Moment of inertia Ixx $=697.2 \times 10^{4} \mathrm{~mm}^{4}$, Iyy $=103.2 \times 10^{4} \mathrm{~mm}^{4}$,

Elastic section modulus Zez $=93 \times 10^{3} \mathrm{~mm}^{3}$

Plastic section modulus $\mathrm{Zpz}=$ bf $\mathrm{xt}_{\mathrm{f}}\left(\mathrm{h}-\mathrm{t}_{\mathrm{f}}\right)+\mathrm{t}_{\mathrm{w}}\left(\mathrm{h}-2 \mathrm{t}_{\mathrm{f}} / 4\right)$ $=83.34 \times 10^{3} \mathrm{~mm}^{3}$

Design bending capacity of the section $\mathrm{Mdz}={ }_{\mathrm{Zpz}} \mathrm{x}\left(\frac{\mathrm{fy}}{\gamma m o}\right)$ $\leq 1.2 \mathrm{x}_{\mathrm{Zez}} \times\left(\frac{\mathrm{fy}}{\gamma m o}\right)$

$\mathrm{Mdz}=18.94 \times 10^{6 \mathrm{Nmm}} \leq 23.94 \times 10^{6} \mathrm{Nmm}$

The actual bending moment is $12.157 \mathrm{kNm}$ and design bending capacity is $18.94 \times 10^{6 \mathrm{~N}} / \mathrm{mm}^{2}$, hence section is safe $18.94 \times 10^{6}>12.157 \mathrm{kNm}$

\section{RESULT AND DISCUSSION}

Overall two methods were designed and comparison of all the internal force, and hence, to evaluate the co-existing moments and shear forces at the critical cross-section with same configuration area by keeping all other parameters constant. The theoretical data are calculated using Indian Standard code IS 800-1984 using working stress method, IS 800-2007 using limit state method, steel table and IS 875part (III) using calculation of wind load recommended. The theoretical results of the limit state method is bending moment and load caring capacity is $76.25 \%$ and $41.35 \%$ higher than the working stress method. Actual deflection and bending stress is same in both the method. But working stress method is more economical method compare to the limit state method. The working stress method, the total weight of steel is required $1502 \mathrm{~kg}$ and total rate of cost is RS 82,610 . The limit state method the total weight of steel is 
required $2308 \mathrm{~kg}$ and total rate of cost is $\mathrm{RS} 126,940$. In this paper investigation, the limit state method is the total quantity of weight of steel and rate of cost is $34.78 \%$ higher than the working stress method. Comparison of rate of the amount for panel length of truss and spacing of truss given in table below

Table 2 Comparison of Weight and Amount by Working stress method and Limit state method for Spacing of the Truss

\begin{tabular}{|l|l|l|l|l|}
\hline \multirow{2}{*}{$\begin{array}{l}\text { Spacing of the } \\
\text { truss in }(\mathbf{m})\end{array}$} & \multicolumn{3}{|l|}{ Limit state method } & Working stress method \\
\cline { 2 - 5 } & Weight in $(\mathbf{k g})$ & Amount $(\mathbf{R S})$ & Weight in $(\mathbf{k g})$ & Amount $(\mathbf{R S})$ \\
\hline $4 \mathrm{~m}$ & 57.65 & 3170.75 & 36.75 & 2021.25 \\
\hline $8 \mathrm{~m}$ & 115.3 & 6341.5 & 73.5 & 4042.5 \\
\hline $12 \mathrm{~m}$ & 172.95 & 9512.25 & 110.25 & 6063.75 \\
\hline $16 \mathrm{~m}$ & 230.6 & 12683 & 147 & 8.85 \\
\hline $20 \mathrm{~m}$ & 288.5 & 15853.75 & 187.75 & 10106.25 \\
\hline
\end{tabular}

Comparison of weight and amount by working stress method is $36.75 \mathrm{~kg}$ and RS 3170.25 centre to centre spacing of the truss and Limit state method is centre to centre
Spacing of the truss $57.65 \mathrm{~kg}$ and rare of the amount is RS 2021.25. The result are shown in table .2 and given in figure 4.

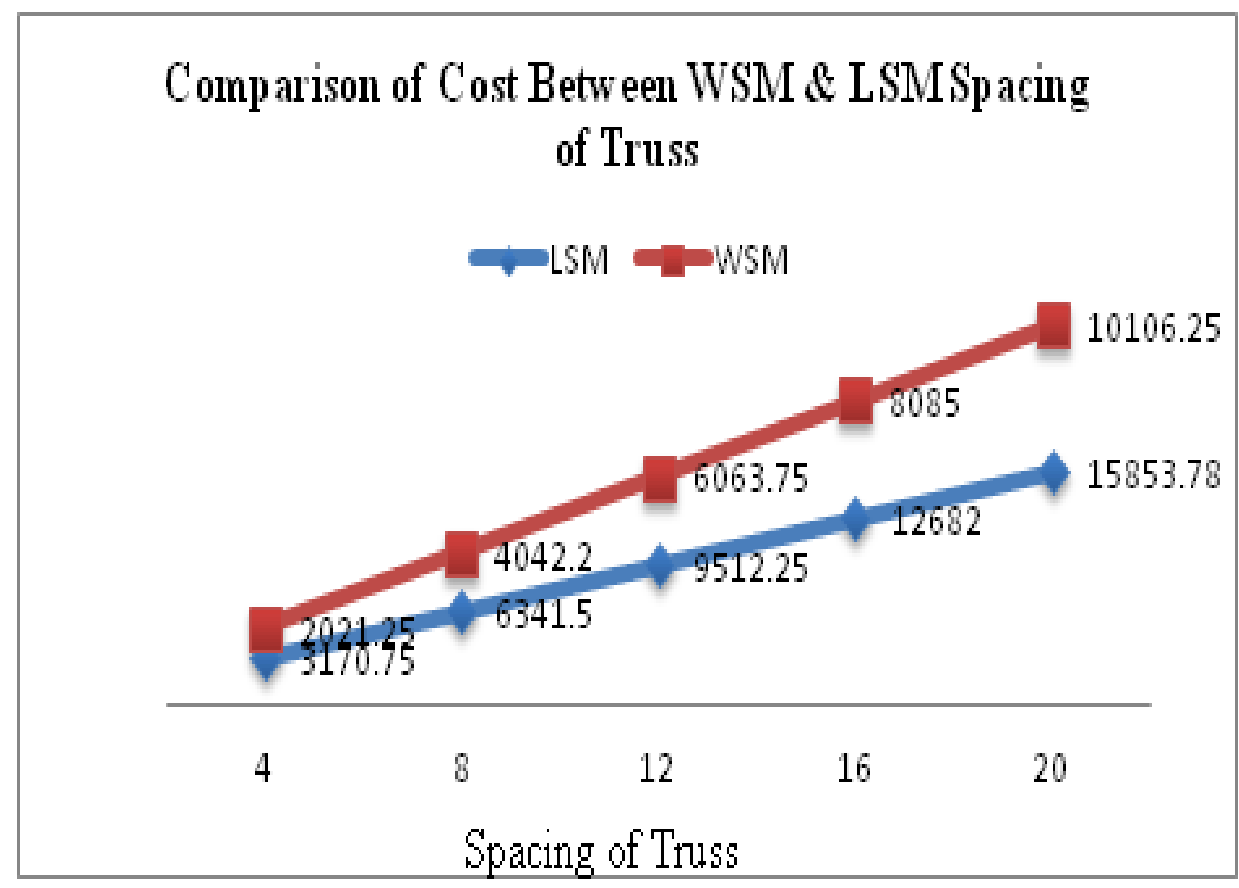

Fig 4 cost between WSM \& LSM spacing of Truss

Table 3 Comparison of Weight and Amount by Working stress method and Limit state method for panel length of the Truss

\begin{tabular}{|l|l|l|l|l|}
\hline \multirow{2}{*}{ Panel length in ( m ) } & \multicolumn{2}{|l|}{ Limit state method } & \multicolumn{2}{l|}{ Working stress method } \\
\cline { 2 - 5 } & Weight in (kg) & Amount (RS) & Weight in (kg) & Amount (RS) \\
\hline 2.25 & 288.5 & 15867.5 & 187.75 & 10326.25 \\
\hline 4.5 & 576.5 & 31212.5 & 375.5 & 20652.5 \\
\hline 6.75 & 864.75 & 47602.5 & 559.25 & 30978.75 \\
\hline 9 & 1153 & 63470 & 751 & 41305 \\
\hline 11.25 & 1441.25 & 79337.5 & 938.75 & 51631.25 \\
\hline 13.5 & 1729.5 & 95205 & 1126.5 & 61957.5 \\
\hline 15.75 & 2017.75 & 111072.5 & 1314.25 & 72283.75 \\
\hline 18 & 2306 & 126830 & 1502 & 82610 \\
\hline
\end{tabular}

Comparison of weight and amount by limit state method is $288.5 \mathrm{~kg}$ and RS 15867.5 for per panel length and $20 \mathrm{~m}$ length of truss and working stress method is $187.75 \mathrm{~kg}$ and rare of the amount is RS 10326.25. The result are shown in table .3 and given in figure 5 . 


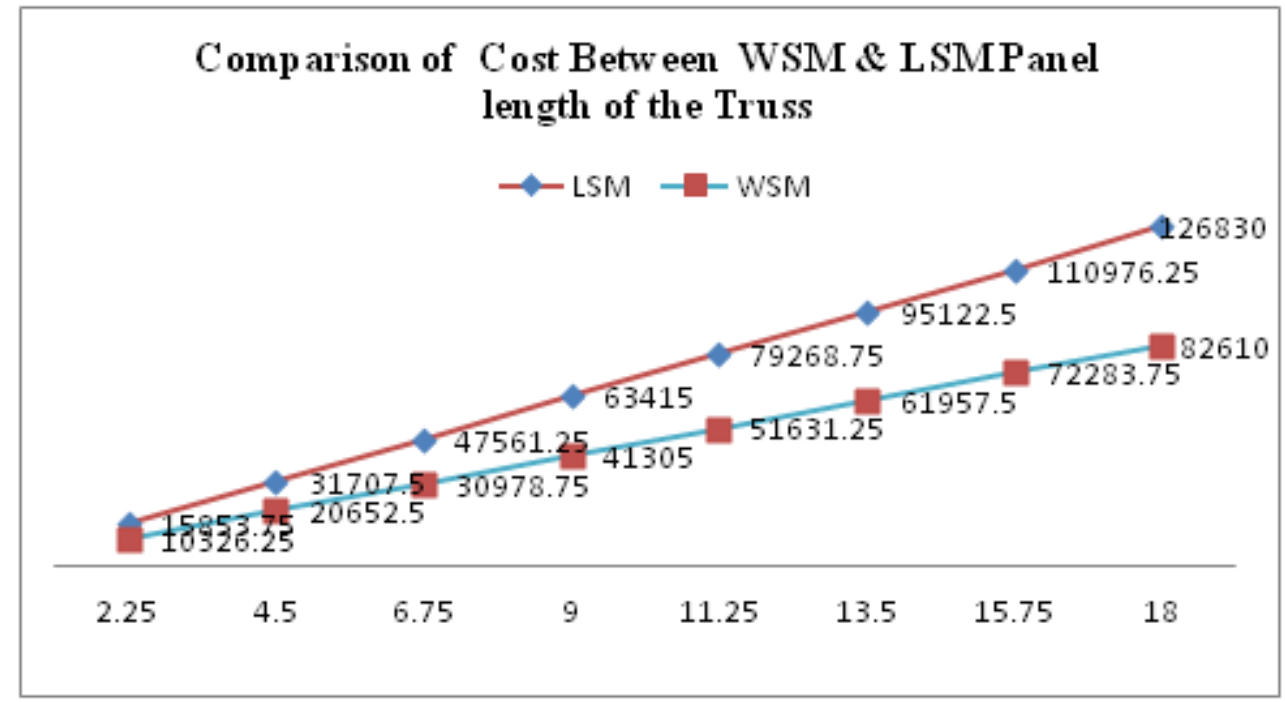

Fig 5.cost between WSM \& LSM panel length of the Truss

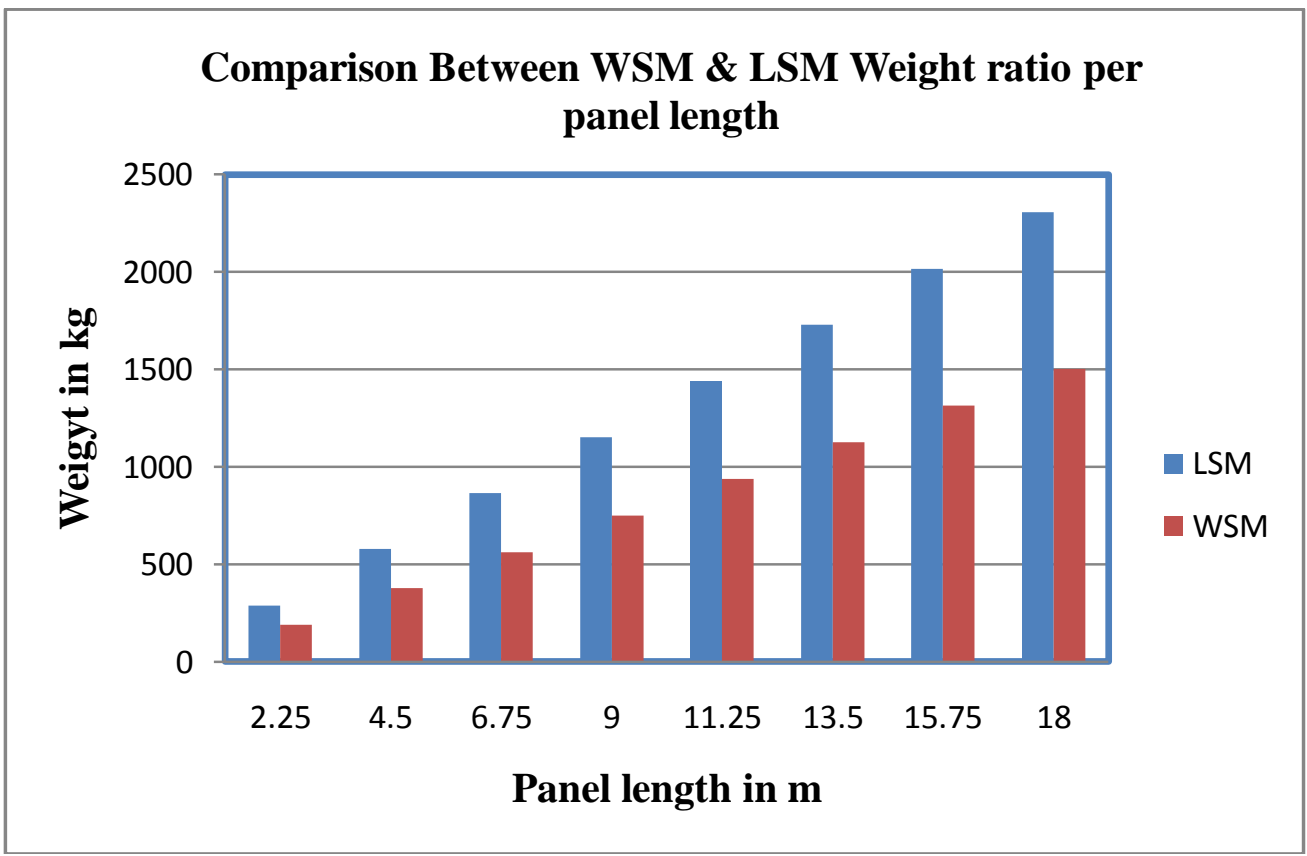

Fig 6 cost between WSM \& LSM spacing of Truss

\section{CONCLUSIONS}

In this paper investigation the total roofing load configuration is same in both the working stress and limit state method. But area of section is $37 \%$ needed for limit state method in compare to the working stress method.

The theoretical results of the limit state method is bending moment and load caring capacity is $76.25 \%$ and $41.35 \%$ higher than the working stress method. Actual deflection and bending stress is same in both the method. But working stress method is more economical method compare to the limit state method. The working stress method, the total weight of steel is required $1502 \mathrm{~kg}$ and total rate of cost is RS 82,610 . The limit state method the total weight of steel is required $2308 \mathrm{~kg}$ and total rate of cost is RS 126,940. In this paper investigation, the limit state method is the total quantity of weight of steel and rate of cost is $34.78 \%$ higher than the working stress method. The studies reveal that the theoretical investigations limit state method design is high bending strength, high load caring capacity, minimum deflection and minimum local buckling\& distortional buckling compare to the working stress method. But working stress method is cost wise most economical method compare to the limit state method design.

The studies reveal that the theoretical investigations limit state method design is high bending strength, high load caring capacity, minimum deflection and minimum local buckling\& distortional buckling compare to the working stress method. But working stress method is most economical compare to the limit state method design. 


\section{REFERENCES}

[1] Anbuchezian .A, Dr. Baskar.G (2013)

"Experimental study on cold formed steel purlin sections" Engineering Science and Technology: An International Journal (ESTIJ), ISSN: 2250-3498, Vol.3, No.2, April 2013276

[2] M. Meiyalagan , M.Anbarasu and Dr.S.Sukumar.(2010) "Investigation on Cold formed C section Long Column with Intermediate Stiffener \& Corner Lips - Under Axial Compression." International journal of applied engineering research, dindigul, Volume 1, No1, 2010

[3] Govindasamy.P, Sreevidya .V, Dr.L.S.Jayagopal "Comparative Study on Cold Form Purlins for Distortional Buckling Behaviour" international journal of engineering sciences \& research Technology ISSN: 2277-9655

[4] Sunil. M.Hardwani, A.V.Patil (2012) "Study, test and designing of cold formed Section as per AISI code." Int. Journal of Applied Sciences and Engineering Research Vol. 1, Issue 3, 2012.

[5] Sanchita.S.Nawale, Sangram Chalukya, and Dr.S.V.Admane "Comparative Analysis and Bending Behavior of Cold form Steel with Hot Rolled Steel Section." American Journal of Engineering Research (AJER) e-ISSN : 2320-0847 p-ISSN : 2320-0936 Volume-03, Issue-05, pp-255261(2013)

[6] P. P. Desai and M. R. Shiyekar (2014) "Limit Strength Prediction of Light Gauge Steel I Section by Finite Element Method." Int. Journal of Engineering Research and Applications, ISSN : 2248-9622, Vol. 4, Issue 7( Version 4), July 2014, pp.111-114 (2014)

[7] F.D. Queiroza , P.C.G.S. Vellascob and D.A. Nethercota (2007) "Finite element modelling of composite beams with full and partial shear connection" Journal of Constructional Steel Research 63 (2007) 505-521 Received 25 January 2006; accepted 8 June 2006 